- expected to handle sequencing and initial analysis, starting with the chimpanzee equivalent of chromosome 21 and other genes suggested by the Brain comparative study of chimpanzees, orang-utans, macaques and gorillas in an attempt to determine the way in which the various different species have evolved.

So far money for the project has not been forthcoming, with each group using funds from some of their other projects to allow the to do the planning. But Naruya Saito, a geneticist at the NIG, hopes that Japan is poised to take the leading role in an international ape sequencing project. He sees it as an opportunity for Japan to "show the world its sequencing capacity".

The project is also notable because it marks the first collaboration between two of Japan's premier research institutes under the auspices of the newly formed Ministry of Education, Culture, Sports, Science and Technology (see Nature 408, $757 ; 2000)$. In the past, rivalry between the various agencies has made such a collaboration difficult. Gemini - the astrological sign of the twins - could therefore represent not only the relationship of genes and the mind, says Saito, but also a new match-up between the NIG and RIKEN.

http://sayer.lab.nig.ac.jp/GEMINI Science Institute. The NIG will run a

\section{Japanese premier underlines opposition to human cloning}

\section{David Cyranoski, Tokyo}

Japan's prime minister, Yoshiro Mori, has warned Japanese researchers to steer clear of a proposed international project to clone humans.

The project, led by Italian in vitro fertilization specialist Severino Antinori and University of Kentucky reproductive physiologist Panos Zavos, aims to help infertile couples have children using the same technology that has been used in animal cloning. The mother's egg would be injected with the father's genetic material and then implanted into her womb.

One project member has predicted that a baby will be born within two years using the technique. But, apart from strong ethical concerns, critics say that the technique's low expected success rate makes it unsuitable for human cloning.

Although many researchers and politicians have chosen to ignore the latest claims being made for the project, reports that a Japanese researcher is involved led to the prime minister's intervention.

A law passed last December, which comes into effect this June, outlaws human cloning in Japan. Mori said he was charging the Ministry of Education, Culture, Sports, Science

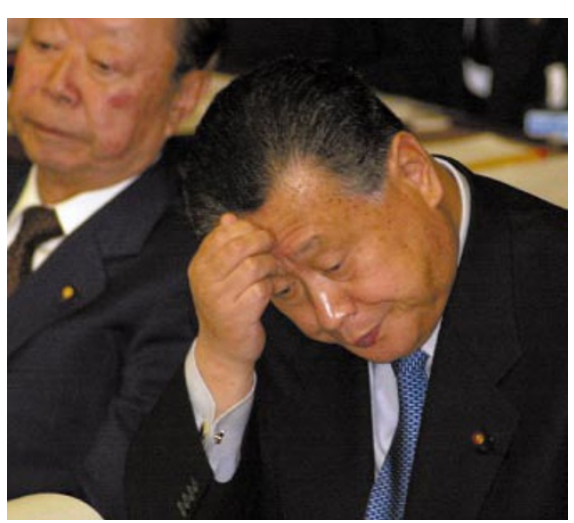

Seeing double: human cloning is a headache for Prime Minister Yoshiro Mori.

and Technology, and Takashi Sasagawa, the science minister, to take steps to keep Japanese researchers out of the project.

"We will try to persuade researchers that what they are doing is wrong and explain that it is a violation of Japanese law," says an official in Sasagawa's office. But participating in such a research project abroad would not directly violate Japanese law — although researchers might be reluctant to defy the government's wishes, and research agencies may cut their funding if they do.

\section{Italian biologists left out in the cold}

\section{Alison Abbott}

Italian research minister Ortensio Zecchino has sown discontent among biologists by committee that he appointed just before

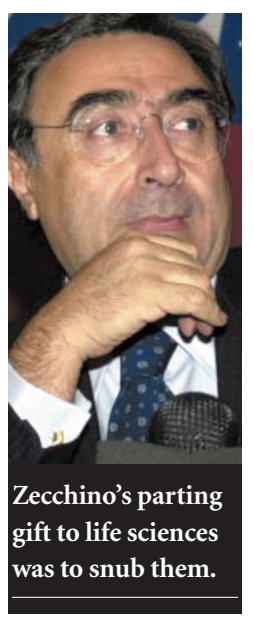
government last week. Zecchino did not in the new eight-strong 'warrant' committee, which will distribute annual grant money of around L250 billion (US\$120 million) to university researchers.

The committee includes two lawyers, a historian and an economist, as well as a chemist, an engineer, a mathematician and a excluding them from a key academic include any life scientists paediatrician. Biologists feel Zecchino has abused his privilege of making the appointments directly, a privilege conferred only recently on the research minister.
In a letter to the newspaper $\mathrm{La}$ Repubblica, 14 Italian heads of scientific societies in the life sciences complained that their discipline was not represented on the committee, although biology accounts for more than a fifth of all grant applications.

"Italian universities require highly qualified evaluators of proposals in biological sciences," says the letter. It asks the prime minister, Giuliano Amato, who is acting as caretaker to the research ministry until the general election this spring, to add an appropriate expert to the committee.

Zecchino left the government to join a new political party, which is positioning itself to take part in the centre-right coalition that is expected to form the next government.

In a separate pre-election development, health minister Umberto Veronesi nominated biochemist Enrico Garaci to become president of the Istituto Superiore di Sanitá, the national health institute, once the statute enabling the position is approved. Garaci is a previous president of the CNR, Italy's national research agency.

\section{Germany targets international talent}

Quirin Schiermeier, Munich

Germany is to offer a small number of élite overseas researchers grant support of DM4.5 million (US\$2.1 million) over three years to work in the country at an institution of their choice.

The Alexander von Humboldt Foundation, an independently administered body financed by the government, will offer between 15 and 20 awards to scientists with international reputations.

Although the main goal of these 'Wolfgang Paul' awards is to attract nonGerman scientists, native Germans are also eligible if they have been working abroad for more than five years.

Recipients will receive up to DM250,000 per year - considerably more than the salary of a full professor in Germany - for 'living costs'. The rest of the money can be used to finance research.

In addition, the foundation will offer 20 or 30 young scientists up to DM2.25 million each over three years.

i http://www.avh.de/en/programme/neu.htm 